\title{
Sexual reproductive effort in the Mediterranean gorgonian Paramuricea clavata
}

\author{
Rafel Coma ${ }^{1,2}$, Mikel Zabala ${ }^{2}$, Josep-Maria Gili ${ }^{1}$ \\ ${ }^{1}$ Institut de Ciències del Mar (CSIC), Passeig Joan de Borbó s/n, E-08039 Barcelona, Spain \\ ${ }^{2}$ Department d'Ecologia, Universitat de Barcelona, Avda, Diagonal 645, E-08028 Barcelona, Spain
}

\begin{abstract}
Sexual reproductive effort in the Mediterranean gorgonian Paramuricea clavata was studied from 1990 to 1993 in a population dwelling at a depth of between 17 and $19 \mathrm{~m}$ off the Medes Islands (northwestern Mediterranean). Variations in polyp fecundity with sex, polyp position within the colony, and colony size were studied, as was interannual variability. Onset of sexual maturity was on average delayed until colonies had attained a size of 20 (11 to 30$) \mathrm{cm}$, i.e. an age of 13 (6 to 19) yr according to our estimates. Male and female colonies of $P$. clavata ripened synchronously and bore fertile polyps on nearly all branch orders. However, the percentage of fertile polyps and the number of gonads per fertile polyp decreased as branch order increased. Accordingly, reproductive effort was highest for polyps on first-order branches, which contributed $85 \%$ of the entire production of gametes. Reproductive effort increased exponentially with colony size due to increases in the percentages of fertile colonies and polyps and in the number of gonads per polyp, at least to a size of $35 \mathrm{~cm}$ in height. No significant interannual variation was detected over the $3 \mathrm{yr}$ study period. The gorgonians present on a representative plot with a surface area of $1 \mathrm{~m}^{2}$ produced, on average, $2 \times 10^{6}$ sperm sacs $(9 \mathrm{~g}$ dry wt of male sex products) and $7 \times 10^{5}$ eggs ( $7 \mathrm{~g}$ dry wt of female sex products). Total reproductive effort was on the order of $9 \mathrm{~g} \mathrm{C} \mathrm{m}^{-2} \mathrm{yr}^{-1}$.
\end{abstract}

KEY WORDS: Gorgonians · Reproductive effort - Gonadal biomass - Intra-colonial variation · Mediterranean

\section{INTRODUCTION}

Recent interest in the ecology of clonal organisms has pointed out the need to develop new models departing from the conventional concepts of population biology, which have traditionally focused on the biology of aclonal organisms (Jackson et al. 1985). Among clonal organisms (1) many demographic parameters such as mortality or reproductive capacity seem to depend less upon age than upon size (Hughes \& Connell 1987, McKinney \& Jackson 1991) and physical condition of the clone (Rinkevich \& Loya 1987) and (2) growth of clones through the addition of modules is potentially unlimited (Strehler 1961), thus explanations of the reproductive strategies of a clonal organisms (Todd 1985) may be inadequate to explain the biology of clonal animals. Specifically, it has been predicted that in clonal organisms: (1) sexual processes can be expected to be deferred while modular growth is unlimited (Connell 1973); (2) perennial, iteroparous forms should prevail over semelparous, ephemeral forms; and (3) reproductive effort, the proportion of metabolic resources devoted to sexual reproduction, should be a graded genetic or phenotypic response to environmental conditions (Hughes \& Cancino 1985). Clonal species dwelling in unstable habitats and hence with short life expectancies might be expected to mature faster and invest a larger share of assimilated energy in sexual reproduction than do species inhabiting more stable habitats. However, reliable data with which to substantiate these hypotheses are lacking. For instance, we have been unable to find any adequate measurements of reproductive effort in corals in the literature (Hughes \& Cancino 1985). It also has been argued that the inability to establish the real size of clones surviving in a number of units (other than by means of costly genetic techniques) makes it impossible to estimate the total fecundity of clones (Hughes 
\& Jackson 1980, Jackson \& Winston 1981). Nevertheless, it is still possible to estimate the reproductive effort in clonal species in which the units have little propensity to fragment or produce stolons. This would appear to be the case for the Mediterranean gorgonian Paramuricea clavata, whose reproductive biology has been described earlier (Coma et al. 1995, this issue). Among gorgonians, quantification of reproductive effort has not gone beyond estimates for modules (polyps) (Theodor 1967, Kinzie 1970, Vighi 1970, Grigg 1977, Martin 1982, Brazeau \& Lasker 1989, 1990), with no integrated results for whole colonies or populations available. The present paper endeavours to quantify reproductive effort in a population of $P$. clavata, a common species in the northwestern Mediterranean, in the framework of a study designed to establish an overall metabolic budget for the species. To assess the reproductive effort, variations in polyp fecundity with sex, polyp position within the colony, and colony size have been studied, together with interannual variations.

\section{MATERIAL AND METHODS}

The population of Paramuricea clavata located near Carall Bernat (Medes Islands, northwestern Mediterranean) was studied from 1990 to 1993 . The population is located at depths between 15 and $27 \mathrm{~m}$ and occupies a surface area of approximately $1000 \mathrm{~m}^{2}$.

Sampling. Samples from the population were collected at depths of 17 to $19 \mathrm{~m}$ by a SCUBA diver. Maximum height (distance from the base to the farthest point) of all colonies sampled was measured to the nearest $0.5 \mathrm{~cm}$. Samples consisted of either colonies or apical fragments and were immediately fixed in $10 \%$ formalin in sea water. At the laboratory, polyps were dissected under a binocular dissecting microscope, and the number of gonads and gonadal diameter were recorded for each polyp. Gonadal volume was estimated from the diameter based on the subspherical shape of the gonads. Total gonadal volume was estimated for each polyp for both sexes.

Reproductive effort. Sexual reproductive effort has been expressed as colony gonadal biomass as a proportion of the organic tissue of the colony, in units of organic carbon. To calculate reproductive effort, the following inputs are required: (1) number of polyps per colony; (2) percentage of fertile polyps and intracolonial variation; (3) total gonadal volume per polyp and intra-colonial variation; (4) gonadal density; and (5) gonadal carbon content.

Production of gametes by the colonies present in a representative $1 \mathrm{~m}^{2}$ plot was also calculated. The inputs required, besides colony reproductive effort, are colony density and the size structure of the population (Coma 1994) along with variation in reproductive effort with colony size. This source of variation was quantified by taking into account: (1) variation in the percentage of fertile colonies; (2) variation in the percentage of fertile polyps; and (3) variation in total gonadal volume per polyp.

Intra-colonial variation. To examine the relationship between reproductive effort and polyp position within the colony, the different branches of the colony were classified following the system used to describe branching patterns in gorgonians (Brazeau \& Lasker 1988, Mitchell et al. 1993). This system defines distal branches as first-order $\left(1^{\circ}\right)$ branches. Higher branch orders arise only when 2 branches of equal lower order join. At the beginning of June 1993, 3 colonies of each sex with heights between 35 and $45 \mathrm{~cm}$ were collected. For each colony 3 replicates consisting of 10 polyps each were collected, and the number of fertile polyps, number of gonads per fertile polyp, and gonadal diameter were recorded. The values were compared by analysis of variance (ANOVA) and Scheffé's contrast test (Zar 1984).

Variation with colony size. The relationship between reproductive effort and colony size was considered by classifying the colonies sampled into $10 \mathrm{~cm}$ size intervals based on maximum colony height, spanning the entire size range of the population ( 1 to $55 \mathrm{~cm}$ ). Before onset of the spawning period in 1991 (beginning of June; Coma et al. 1995), apical fragments were collected from 10 male and 10 female colonies in each size class. Five polyps from each fragment were examined, and the number of gonads present and gonadal diameter were recorded.

Gonadal biomass. At the beginning of June 1993, during the period of gonadal ripening, 3 colonies of Paramuricea clavata were collected, and 5 replicates of 200 unfixed ovaries each and another 5 replicates of 200 unfixed sperm sacs (male gonads) each were collected. The diameter of each gonad was measured, gonadal volume estimated, and total gonadal volume calculated for each replicate. Mature $P$. clavata ovaries contain only a single oocyte within a thin layer of tissue (Coma 1994). Consequently, ovarial volume can be taken as representative of oocyte volume. After the measurements were taken, the replicates were dried in an oven at $70^{\circ} \mathrm{C}$ for $24 \mathrm{~h}$ and weighed using a microbalance (precision: $0.1 \mu \mathrm{g}$ ) to obtain the dry weight value of each replicate. Next, the replicates were heated in an oven at $550^{\circ} \mathrm{C}$ for $5 \mathrm{~h}$. The ashes were weighed and the ash-free dry weight (AFDW) calculated for each. In no case did the ashes exceed $2 \%$ of replicate dry weight.

Mean ovarian and sperm sac densities were calculated based on the dry weight to total gonadal volume 
Table 1. Paramuricea clavata. Mean ( \pm SD) diameter ( $n=$ number of gonads; 5 samples of 200 gonads), dry weight, density, and carbon content $(\mathrm{C})$ for mature oocytes and sperm sacs

\begin{tabular}{|lcccccccc|}
\hline & $\begin{array}{c}\text { Diameter } \\
(\mu \mathrm{m})\end{array}$ & $\mathrm{n}$ & $\begin{array}{c}\text { Dry weight } \\
(\mathrm{mg})\end{array}$ & $\mathrm{n}$ & $\begin{array}{c}\text { Density } \\
\left(\mathrm{mg} \mathrm{mm}^{-3}\right)\end{array}$ & $\mathrm{n}$ & C/dry wt & $\mathrm{n}$ \\
\hline Oocyte & $342 \pm 43$ & 731 & $0.010 \pm 0.0010$ & 5 & $0.47 \pm 0.03$ & 5 & $0.59 \pm 0.07$ & 5 \\
Sperm sacs & $281 \pm 129$ & 1725 & $0.005 \pm 0.0005$ & 5 & $0.38 \pm 0.04$ & 5 & $0.53 \pm 0.01$ & 5 \\
\hline
\end{tabular}

ratio for each sex in the 5 replicates. Both mean density values were later used to estimate ovarian and sperm sac biomass based on gonadal diameter.

At the same time a further 5 replicates of 200 ovaries each and 5 replicates of 200 sperm sacs each were collected. The carbon content of each replicate was determined using a Carlo-Erba model 1500 C:N elementary analyzer (Table 1).

Interannual variability. A total of 10 male colonies and 10 female colonies between 30 and $50 \mathrm{~cm}$ in height were tagged in the same study area. An apical fragment from each was collected at the beginning of June 1991, 1992 and 1993. Gonadal volume was measured for 5 polyps from each colony per sample. Interannual variability was considered for number of gonads produced (female gonads $>200 \mu \mathrm{m}$, male gonads $>$ $150 \mu \mathrm{m})$, and the values for number of gonads converted to total volume and dry weight per polyp.

\section{RESULTS}

\section{Intra-colonial variation}

Male and female colonies of Paramuricea clavata ripen sexually synchronously and bear fertile polyps on all branches except $5^{\circ}$ branches. However, the percentage of fertile polyps decreases with increasing branch order on colonies of both sexes (Table 2; ANOVA, p < 0.005). Also the number of gonads per fertile polyp fell off significantly with increasing branch order on colonies of both sexes (Table 2; ANOVA, $\mathrm{p}<0.001$ ):

$$
\begin{array}{ll}
\text { Male colonies } & 1^{\circ} 2^{\circ} \underline{3^{\circ} 4^{\circ}} \\
\text { Female colonies } & 1^{\circ} 2^{\circ} \underline{3^{\circ} 4^{\circ}}
\end{array}
$$

The fecundity of $1^{\circ}$ branches was higher in that they had a higher percentage of fertile polyps and more gonads per polyp. Furthermore, since they make up the largest share of colony biomass (Coma 1994), they contribute $85 \%$ of all gametes and were thus the main contributors to sexual reproduction by the colonies. Mean diameter of ripe male $(\bar{x} \pm \mathrm{SD}, 254.1 \pm 46 \mu \mathrm{m})$ and female $(235.1 \pm 79 \mu \mathrm{m})$ gonads did not vary significantly with branch order (ANOVA, $\mathrm{p}>0.05$ ).

\section{Variation with colony size}

The percentage of gonad-bearing colonies increased with size (Fig. 1). Most colonies (around $70 \%$ ) belonging to the first size class (between 0 and $10 \mathrm{~cm}$ tall) had no gonads (Fig. 1). In the following 2 size classes the percentage of colonies with gonads rose rapidly, reaching $100 \%$ at heights above $30 \mathrm{~cm}$. The smallest fertile male colony (with sperm-containing sperm sacs) was $8 \mathrm{~cm}$ in size. No female colonies smaller than $11 \mathrm{~cm}$ with ripe gonads (ovaries with mature oocytes) were observed. From a height of $30 \mathrm{~cm}$ all colonies were fertile. On average, sexual maturity was delayed until colonies had reached a size of $20(11$ to 30$) \mathrm{cm}$, i.e. an age of 13 (6 to 19) yr according to our estimates (Coma 1994). The number of gonads per polyp increased significantly (ANOVA, $\mathrm{p}<0.001$ ) with colony size (Table 3). In contrast, the diameter of ripe male and female gonads did not vary with colony size (ANOVA, p > 0.05). Fecundity increased in both sexes with colony size because of the higher percentages of fertile colonies and polyps and a larger number of gonads per polyp (Table 3). Gonadal biomass in colonies $39 \mathrm{~cm}$ tall was thus approximately double that of colonies $30 \mathrm{~cm}$ high and some 4 times that of colonies $25 \mathrm{~cm}$ in size (Fig. 2).

Table 2. Paramuricea clavata. Percentage of fertile polyps, number of gonads per fertile polyp, and gonadal volume per fertile polyp in male and female colonies according to branch order. Values are mean $\pm \mathrm{SE}$; $\mathrm{n}$; number of colonies examined

\begin{tabular}{|ccccc|}
\hline $\begin{array}{l}\text { Branch } \\
\text { order }\end{array}$ & $\begin{array}{c}\% \text { Fertile } \\
\text { polyps }\end{array}$ & $\begin{array}{c}\text { No. of } \\
\text { gonads }\end{array}$ & $\begin{array}{c}\text { Volume } \\
\left(\mathrm{mm}^{3}\right)\end{array}$ & $\mathrm{n}$ \\
\hline $\begin{array}{c}\text { Male } \\
1^{\circ}\end{array}$ & 100 & $25.7 \pm 4.2$ & $0.53 \pm 0.16$ & 3 \\
$2^{\circ}$ & $95.5 \pm 10.1$ & $14.3 \pm 4.8$ & $0.26 \pm 0.16$ & 3 \\
$3^{\circ}$ & $59 \pm 39.2$ & $5.2 \pm 2.2$ & $0.07 \pm 0.04$ & 3 \\
$4^{\circ}$ & $31.1 \pm 37.9$ & $2.8 \pm 0.6$ & $0.03 \pm 0.01$ & 3 \\
$5^{\circ}$ & 0 & 0 & 0 & 3 \\
Female & & & & \\
$1^{\circ}$ & $93.3 \pm 14.1$ & $12.8 \pm 6.4$ & $0.27 \pm 0.14$ & 3 \\
$2^{\circ}$ & $82.2 \pm 21.6$ & $7.4 \pm 4.2$ & $0.15 \pm 0.09$ & 3 \\
$3^{\circ}$ & $67.7 \pm 30.7$ & $4.2 \pm 2.3$ & $0.09 \pm 0.06$ & 3 \\
$4^{\circ}$ & $23.3 \pm 39.4$ & $6.3 \pm 3.1$ & $0.14 \pm 0.09$ & 3 \\
\hline
\end{tabular}




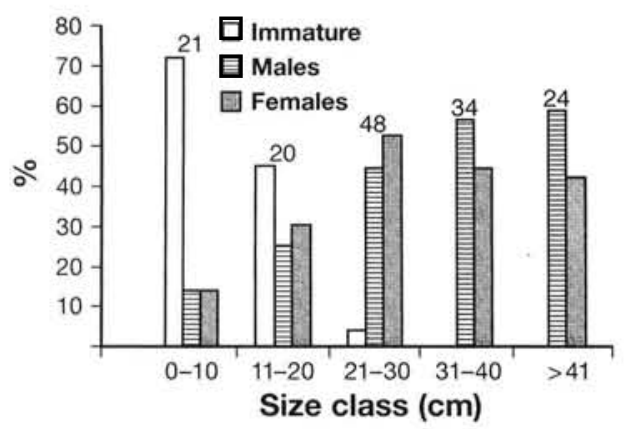

Fig. 1. Paramuricea clavata. Sex ratio and proportion of immature colonies on colony size (10 cm size classes); number of colonies examined in each size class written above the bars

We considered 2 different manifestations of sexual senescence in this species; (1) a decline in fecundity and (2) cessation of sexual reproduction. It was possible to determine the sex of all colonies larger than $30 \mathrm{~cm}$ in height, and no decline in fecundity was observed with size, assuming that size equals age (see specific data in Coma 1994). Rather, colony fecundity was higher in the larger specimens in the study population (maximum colony height: $57 \mathrm{~cm}$ ).

\section{Interannual variability}

There were no significant differences in the number of ripe gonads per polyp or in gonadal volume in either sex over the 3 yr considered (Table 4).

\section{Reproductive effort}

Reproductive effort of colonies increased with colony size (Fig. 3). Colonies smaller than $10 \mathrm{~cm}$ invested be-

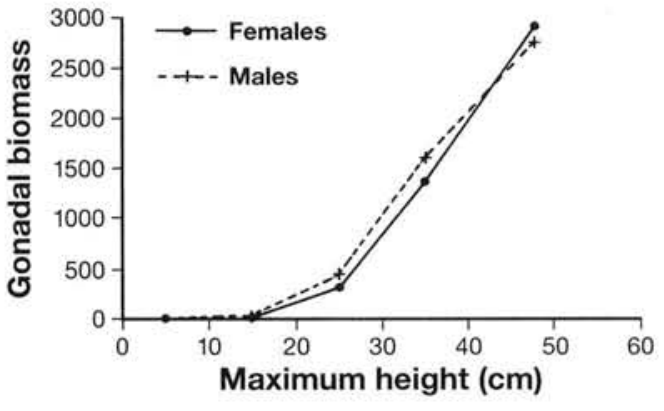

Fig. 2. Paramuricea clavata. Gonadal biomass (mg dry weight) for male and female colonies with respect to colony height

tween 0.2 and $2 \%$ of their biomass, expressed as organic carbon weight of tissue, in reproductive effort, whereas colonies larger than $40 \mathrm{~cm}$ invested between 84 and $98 \%$ of the carbon weight of tissue. The increasing trend in reproductive effort levelled off somewhat at a height of approximately $35 \mathrm{~cm}$, when reproductive effort had reached levels of around $80 \%$.

The number of sperm sacs produced by the male colonies in a representative $1 \mathrm{~m}^{2}$ plot $\left(56\right.$ colonies $\left.\mathrm{m}^{-2}\right)$ was 2053940 , substantially higher than the 729516 oocytes produced by the female colonies (Table 5). However, in terms of biomass, the contribution to the community was very similar in the 2 sexes, $9 \mathrm{~g}$ dry wt $\mathrm{m}^{-2} \mathrm{yr}^{-1}$ for males, $7 \mathrm{~g}$ dry wt $\mathrm{m}^{-2} \mathrm{yr}^{-1}$ for females. When expressed in terms of carbon, the contribution to the plankton of reproduction in this species was on the order of $9 \mathrm{~g} \mathrm{C} \mathrm{m}^{-2} \mathrm{yr}^{-1}$ (Table 5).

\section{DISCUSSION}

The development and release of mature gametes was observed in the same colonies of Paramuricea

Table 3. Paramuricea clavata. Mean ( \pm SE) reproductive effort values according to colony size: percentage of fertile colonies and of fertile polyps, number of gonads per fertile polyp, gonadal volume per fertile polyp, and total gonadal volume per fertile polyp. $\mathrm{n}$ : number of colonies examined. Maturity of gonads not determined in females

\begin{tabular}{|c|c|c|c|c|c|c|c|c|}
\hline \multirow{2}{*}{$\begin{array}{l}\text { Size } \\
(\mathrm{cm})\end{array}$} & \multirow{2}{*}{$\begin{array}{c}\% \text { Fertile } \\
\text { colonies }\end{array}$} & \multirow{2}{*}{$\begin{array}{l}\% \text { Fertile } \\
\text { polyps }\end{array}$} & \multicolumn{2}{|c|}{ No. of gonads } & \multicolumn{2}{|c|}{ Volume $\left(\mathrm{mm}^{3}\right)$} & \multirow{2}{*}{$\begin{array}{c}\text { Total } \\
\text { volume }\left(\mathrm{mm}^{3}\right)\end{array}$} & \multirow[t]{2}{*}{$\mathrm{n}$} \\
\hline & & & Immature & Mature & Immature & Mature & & \\
\hline \multicolumn{9}{|l|}{ Male } \\
\hline $0-10$ & 29 & $60(40)$ & $7.3(5.4)$ & - & 0.001 & 0 & 0.0002 & 10 \\
\hline $11-20$ & 55 & $43.3(32)$ & $6.9(6.9)$ & $1.5(0.8)$ & 0.001 & 0.031 & 0.0077 & 10 \\
\hline $21-30$ & 95 & $64.3(28.5)$ & $10.1(4.5)$ & $7.7(5.2)$ & 0.001 & 0.161 & 0.0990 & 10 \\
\hline $31-40$ & 100 & $80(31.6)$ & $26.3(8.5)$ & $14(6.1)$ & 0.004 & 0.293 & 0.2377 & 10 \\
\hline$>40$ & 100 & $82(29)$ & $28.7(5.9)$ & $18(7.5)$ & 0.004 & 0.377 & 0.3127 & 10 \\
\hline \multicolumn{9}{|c|}{ Female } \\
\hline $0-10$ & 29 & $80(20)$ & \multicolumn{2}{|c|}{$3.7(3.5)$} & \multicolumn{2}{|c|}{0.09} & 0.02 & 10 \\
\hline $11-20$ & 55 & $64(22)$ & \multicolumn{2}{|c|}{$\begin{array}{l}13.1(4.5) \\
20.5(20)\end{array}$} & \multicolumn{2}{|c|}{$\begin{array}{l}0.15 \\
0.24\end{array}$} & 0.054 & 10 \\
\hline $21-30$ & 95 & $92(10.9)$ & \multirow{2}{*}{\multicolumn{2}{|c|}{$\begin{array}{l}20.5(20) \\
30.2(8.2)\end{array}$}} & \multirow{2}{*}{\multicolumn{2}{|c|}{0.24}} & 0.208 & 10 \\
\hline $31-40$ & 100 & $92.7(13.5)$ & & & & & 0.325 & 10 \\
\hline$>40$ & 100 & $98(6.3)$ & \multicolumn{2}{|c|}{$36.1(9.7)$} & \multicolumn{2}{|c|}{0.42} & 0.411 & 10 \\
\hline
\end{tabular}


Table 4. Paramuricea clavata. Interannual variation in the number and volume $\left(\mathrm{mm}^{3}\right)$ of mature oocytes and sperm sacs per polyp in the period 1991-1993 and analysis of variance (ANOVA) of the level of significance ( $F$ : Fisher's F-statistic; SE: standard error, $\mathrm{n}$ : number of polyps examined)

\begin{tabular}{|c|c|c|c|c|c|c|c|}
\hline Measure & & 1991 & 1992 & 1993 & df & $F$ & $\mathrm{p}$ \\
\hline \multirow[t]{2}{*}{ Oocyte per polyp } & $\bar{x}$ & 12.9 & 14.7 & 12.3 & 2.187 & 1.02 & 0.362 \\
\hline & SE & 1.05 & 1.85 & 0.82 & & & \\
\hline \multirow[t]{3}{*}{ Volume per polyp } & $\bar{x}$ & 0.27 & 0.31 & 0.26 & 2.187 & 1.11 & 0.332 \\
\hline & SE & 0.02 & 0.04 & 0.02 & & & \\
\hline & $\mathrm{n}$ & 50 & 50 & 90 & & & \\
\hline \multirow[t]{2}{*}{ Sperm sacs per polyp } & $\bar{x}$ & 26.6 & - & 25.7 & 1.138 & 0.09 & 0.756 \\
\hline & SE & 3.55 & - & 0.91 & & & \\
\hline \multirow[t]{3}{*}{ Volume per polyp } & $\bar{x}$ & 0.62 & - & 0.53 & 1.138 & 1.81 & 0.180 \\
\hline & $\mathrm{SE}$ & 0.08 & - & 0.03 & & & \\
\hline & $\mathrm{n}$ & 50 & - & 90 & & & \\
\hline
\end{tabular}

clavata over a 4 yr period (1990 to 1993) and confirmed the iteroparous nature of the species, whose individuals partition their reproductive effort over successive annual periods over their lifetimes. This pattern has also been reported for different tropical species, such as Briareum asbestinum (Brazeau \& Lasker 1990) and Plexaura A (H. R. Lasker pers. comm.).

\section{Intra-colonial variation}

Consideration of reproductive effort on the basis of the branching pattern classification system postulates similar functional characteristics for all segments on a given branch order (Brazeau \& Lasker 1988). Observations in Paramuricea clavata bore out such functional similarity, in that spatial variability in the polyp fecundity within a colony was much lower within each order than between orders. The high fecundities recorded for the apical segments of $P$. clavata contrasts with the findings reported for Briareum asbestinum (Brazeau \& Lasker 1990), the only other gorgonian species in which intra-colonial variability in fecundity has been studied. In this latter species, fecundity was

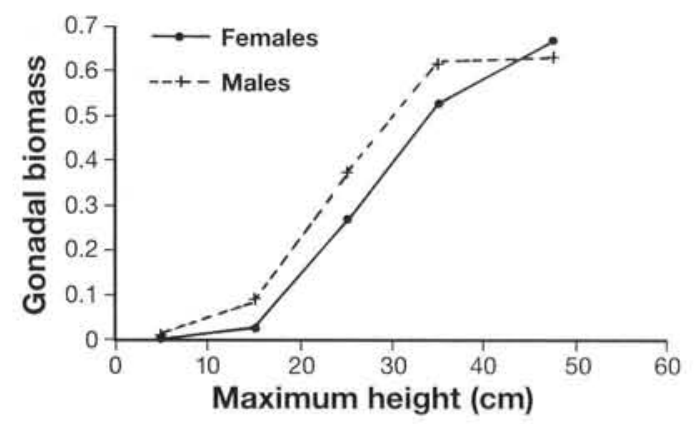

Fig. 3. Paramuricea clavata. Reproductive effort in terms of gonadal biomass ( $\mu \mathrm{g} \mathrm{C} \mu \mathrm{g}^{-1}$ organic $\mathrm{C}$ in colony tissue) with respect to colony height

highest among polyps on the central portions of branches. The morphology, stolonal strategy, and high growth rate, and the importance of vegetative reproduction in this tropical species (Lasker 1983) may be some of the main factors responsible for this difference. The pattern followed by $B$. asbestinum is similar to that observed in corals with localized growth zones and, additionally, high growth rates (Rinkevich \& Loya 1979, Oliver 1984, Wallace 1985, Kojis 1986a, Soong \&

Table 5. Paramuricea clavata. Mean annual gonadal production in number, dry weight, and carbon in male and female colonies per $\mathrm{m}^{2}$ of substratum occupied by the population studied

\begin{tabular}{|c|c|c|c|c|c|c|c|c|c|}
\hline $\begin{array}{l}\text { Size } \\
(\mathrm{cm})\end{array}$ & $\begin{array}{l}\text { Oocytes } \\
\text { col. }^{-1} \\
\text { (n) }\end{array}$ & $\begin{array}{c}\text { Sperm } \\
\text { sacs col. }^{-1} \\
\text { (n) }\end{array}$ & $\begin{array}{c}\text { Density } \\
\left(\mathrm{col} . \mathrm{m}^{-2}\right)\end{array}$ & $\begin{array}{l}\text { Oocytes } \\
\mathrm{m}^{-2} \\
\text { (n) }\end{array}$ & $\begin{array}{c}\text { Sperm } \\
\text { sacs } \mathrm{m}^{-2} \\
\text { (n) }\end{array}$ & $\begin{array}{c}\text { Oocytes } \\
\mathrm{m}^{-2} \\
\text { (mg dry wt) }\end{array}$ & $\begin{array}{c}\text { Sperm } \\
\text { sacs } \mathrm{m}^{-2} \\
\text { (mg dry wt) }\end{array}$ & $\begin{array}{l}\text { Oocytes } \\
\mathrm{m}^{-2} \\
(\mathrm{mg} \mathrm{C})\end{array}$ & $\begin{array}{c}\text { Sperm } \\
\text { sacs m }^{-2} \\
(\mathrm{mg} \mathrm{C})\end{array}$ \\
\hline $10-20$ & 1100 & 14113 & 19.6 & 10778 & 138307 & 106 & 611 & 63 & 324 \\
\hline $20-30$ & 31734 & 118172 & 9.4 & 149148 & 555410 & 1468 & 2452 & 866 & 1300 \\
\hline $30-40$ & 135473 & 330164 & 4.1 & 277719 & 676836 & 2734 & 2988 & 1613 & 1584 \\
\hline
\end{tabular}


Lang 1992). The low growth rate in P. clavata (Coma 1994 ) is the reason fertility of apical polyps is possible. Decreasing fecundity with increasing branch order could be related to the different prey capture rates for polyps on the different branch orders, probably as a result of differences in access to water flow. Murdock (1978) estimated substantial potential flow rates for metabolites through the axial channels of colonies, which would in theory enable ingested matter to be transported throughout the entire colony; however, those same authors reported that in practice most such matter normally seems to be distributed within the region lying in the vicinity of the point of capture. Soong \& Lang (1992) observed infertility in the basal portions of Acropora cervicornis and Porites furcata and they also suggest low food availability could be the cause.

\section{Variation with colony size}

The size at first reproduction is lower in other species studied (Grigg 1977, Martin 1982, Brazeau \& Lasker $1989,1990)$. However, bearing in mind the low rate of growth in this species (Coma 1994), the minimum age at first reproduction can be estimated at around 7 to $13 \mathrm{yr}$, placing Paramuricea clavata among the slowest species to reach sexual maturity. Size at first reproduction is highly variable, as has been reported for other gorgonians (Brazeau \& Lasker 1989, Wahle 1983); this would appear to be attributable to the high plasticity of clonal organisms, in which there may be considerable divergence in growth, survival, and fecundity in individuals the same age (Caswell 1982, Hughes \& Cancino 1985).

Colonies larger than $40 \mathrm{~cm}$ were very scarce in the population studied (less than $3 \%$ ), yet their contribution to the production of gametes was on the order of $40 \%$ of female gametes and $33 \%$ of male gametes. Higher fecundity levels with size means that the likelihood of reproductive success increases with colony size. Also other factors such as fertilization success and spatial location may ultimately determine reproductive success. McKinney \& Jackson (1991) discussed these aspects in relation to certain populations of bryozoans and suggested that in such cases the evolutionary advantage of attaining a large colony size must be extremely great, because in some species a few clones may dominate the population genetically (Coffroth et al. 1992). This is one hypothesis postulated to account for the considerable delay in the onset of sexual reproduction that is characteristic in many clonal organisms (Hughes \& Cancino 1985). Other non-exclusive interpretations of such delays have, however, also been put forward. Investment of resources nearly exclusively in growth during the critical early years of life may also be evolutionarily advantageous (Connell 1973) by: (1) enhancing the likelihood of survival associated with larger size (Kojis \& Quinn 1981, Martin 1982, SzmantFroelich 1986); (2) increasing future reproductive success through the greater availability of resources provided by larger size (Szmant-Froelich 1985); and (3) avoiding the cost of sex by achieving high exponential growth rates during periods of unlimited growth through modular replication (Allan \& Goulden 1980). All these interpretations agree on the importance of attaining a minimum size before investing in sexual reproduction. This pattern of higher fecundity with colony size appears to be generalized among gorgonians (Kinzie 1974, Grigg 1977, Wahle 1983). This pattern also seems to be widespread among corals (Kojis \& Quinn 1981, Tranter et al. 1982, Babcock 1984, 1986, Wallace 1985), although exceptions have been described, as in Porites astreoides, in which fecundity is correlated with age rather than with colony size (Chornesky \& Peters 1987), or in Pocillopora damicornis, in which fecundity was not significantly correlated with colony size (Richmond 1987).

No evidence of reproductive senescence has been observed in Paramuricea clavata, just as none was found in Plexaura homomalla (Martin 1982). A number of workers (Medawar 1957, Williams 1957, Hamilton 1966) have predicted that the onset of senescence should occur later in organisms with relatively low rates of adult mortality and constantly increasing fecundity levels than ... species with relatively high rates of adult mortality (by predators or pulling up by divers) and limited adult fecundity. Although fecundity levels have been reported to decrease in large colonies in certain species of corals (Holloran 1986), symptoms of senescence in clonal species like Paramuricea clavata could be expected to appear late, perhaps so late as to be virtually undetectable under natural conditions (Harper 1981, 1985, Palumbi \& Jackson 1983, Silander 1985).

\section{Interannual variability}

Paramuricea clavata did not exhibit any interannual variation in fecundity over the $4 \mathrm{yr}$ period considered. Similarly, Brazeau \& Lasker (1990) did not record any significant differences in the fecundity of female colonies of Briareum asbestinum in the Caribbean. On the other hand, significant interannual differences have been observed in certain species of corals off eastern Australia (Wallace 1985) and in the Red Sea (Rinkevich \& Loya 1987). Longer-term studies monitoring possible variability are called for, since to date no study has lasted for more than $4 \mathrm{yr}$. 


\section{Reproductive effort}

Reproductive effort in gorgonians has been assessed by most researchers (Theodor 1967, Kinzie 1970, Vighi 1970, Grigg 1977, Martin 1982, Brazeau \& Lasker 1989, 1990) as fecundity expressed as number of oocytes, number of eggs, or number of planulae per polyp. These estimates furnish useful indices of reproductive effort, provided that the size of oocytes and planulae and the number of annual reproductive cycles are reasonably constant (Kojis 1986b, Harrison \& Wallace 1990). Paramuricea clavata appears to be the species that makes the highest investment in sexual reproduction in terms of number of mature oocytes produced per polyp (Theodor 1967, Kinzie 1970, Vighi 1970, Grigg 1977, Martin 1982, Brazeau \& Lasker 1989, 1990). Validation of this supposition requires estimates of somatic biomass for the other species; in any event, the high fecundity of $P$. clavata ranks this species among the gorgonians with the highest investment in sexual reproduction of all those studied to date. This pattern of behaviour in P. clavata is in consonance with the general observation that the number of offspring is related to the broad characteristics of the habitat, with generally higher values in temperate regions with variable climates than in tropical regions (Margalef 1984).

The estimates of reproductive effort levels for Paramuricea clavata colonies, ranging up to $98 \%$ of their tissue biomass, cannot be contrasted with values for other species of gorgonians. At the beginning of its spawning period, the hydroid Orthopyxis crenata invests up to $10 \%$ of its biomass in reproduction daily (Coma 1994). Colonies of Pocillopora damicornis release between 25 and $50 \%$ of their total colony weight annually, and 1 colony released $4 \%$ of its tissue weight as planulae in just $48 \mathrm{~h}$ (Jokiel 1985). Richmond (1987) quantified spawning in $P$. damicornis at between 20 and $167 \%$ (mean: $62 \%$, irrespective of colony size) of colony calorie content annually.

The estimated production of $730000 \mathrm{eggs} \mathrm{m}^{-2}$ for the population is much higher than the level of larval production estimated by Theodor (1967) for Eunicella singularis in the Mediterranean (60000 larvae $\mathrm{m}^{-2}$ ). This discrepancy may be the result of differences in the densities of spawning colonies, though it may also be attributable to low fertilization rates. However, no percentage fertilization rates are available for Paramuricea clavata, although in situ fertilization has been reported to be low in other species of gorgonians (Brazeau \& Lasker 1992). In conclusion, the results of this study have contributed to our knowledge of the biology of clonal organisms by verifying the iteroparuty of this species, the absence of senescence in natural populations, and the dependence between reproductive efficiency and colony size.
Acknowledgements: The authors gratefully acknowledge the helpful assistance of the colleagues who have collaborated in the Medes Islands research programme. We also thank Dr V. Alvà, Dr R. G. Hughes, Dr H. R. Lasker and 3 anonymous reviewers for their critical reviews of the manuscript and Mr R. Sacks for his help in preparing the English version. This work was supported by CICYT grant, contract number PB91-0906.

\section{LITERATURE CITED}

Allan, J. D., Goulden, C. E. (1980). Some aspects of reproductive variation among freshwater zooplankton. In: Kerfoot, W. C. (ed.) Evolution and ecology of zooplankton communities. Univ. Press of New England, Hanover, p. 338-410

Babcock, R. C. (1984). Reproduction and distribution of two species of Goniastrea (Scleractinia) from the Great Barrier Reef Province, Coral Reefs 2: 187-195

Babcock, R. C. (1986). Population biology of reef flat corals of the family Faviidae (Goniastrea, Platygyra). Ph.D. thesis, James Cook University of North Queensland, Townsville

Brazeau, D. A., Lasker, H. R (1988). Inter- and intraspecific variation in gorgonian colony morphology: quantifying branching patterns in arborescent animals. Coral Reefs 7: $139-143$

Brazeau, D. A., Lasker, H. R. (1989). The reproductive cycle and spawning in a Caribbean Gorgonian. Biol. Bull. 176: $1-7$

Brazeau, D. A., Lasker, H. R. (1990). Sexual reproduction and external brooding by the Caribbean gorgonian Briareum asbestinum. Mar. Biol. 104: 465-474

Brazeau, D. A., Lasker, H. R. (1992). Reproductive success in the Caribbean octocoral Briareum asbestinum. Mar. Biol. 114: 157-163

Caswell, H. (1982). Optimal life histories and the maximization of reproductive value: a general theorem for complex life cycles. Ecology 63: 1218-1222

Chornesky, E. A., Peters, E. C. (1987). Sexual reproduction and colony growth in the scleractinian coral Porites astreoides. Biol. Bull. 172: 161-177

Coffroth, M. A., Lasker, H. R., Diamond, M. E., Bruenn, J. A., Bermingham, E. (1992). DNA fingerprints of a gorgonian coral: a method for detecting clonal structure in a vegetative species. Mar. Biol. 114: 317-325

Coma, R. (1994). Evaluación del balance energético de dos especies de cnidarios bentónicos. Ph.D. thesis, University of Barcelona

Coma, R., Ribes, M., Zabala, M., Gili, J. M. (1995). Reproduction and cycle of gonadal development in the Mediterranean gorgonian Paramuricea clavata. Mar. Ecol. Prog. Ser. 117: 173-183

Connell, J. H. (1973). Population ecology of reef corals, In: Jones, O. A., Endean, R. (eds.) Biology and geology of coral reefs, Vol. 2, Biol. 1. Academic Press, New York, p. 205-245

Grigg, R. W. (1977). Population dynamics of two gorgonian corals. Ecology 58: 278-290

Hamilton, W. D. (1966). The moulding of senescence by natural selection. J, theor. Biol. 12: 12-45

Harper, J. L. (1981). The concept of population in modular organisms. In: May, R. M. (ed.) Theoretical ecology. MA Sinauer Associates, Sunderland, p. 53-77

Harper, J. L. (1985). Modules, branches, and the capture of resources. In: Jackson, J. B. C., Buss, L. W., Cook, R. E. (eds.) Population biology and evolution of clonal organisms. Yale University Press, New Haven, p. 1-33 
Harrison, P. S., Wallace, C. C. (1990). Reproduction, dispersal and recruitment of scleractinian corals. In: Dubinsky, $\mathrm{Z}$. (ed.) Ecosystems of the world. Elsevier, Amsterdam, p. $133-204$

Holloran, M. K. (1986). The relationship between colony size and larva production in the reef coral Pocillopora damicornis. In: Jokiel, P. L., Richmond, R. H., Rogers, R. A. (eds.) Coral reef population biology. Hawaii Inst. mar. Biol. Tech. Rep. 37: 167-169

Hughes, R. N., Cancino, J. M. (1985). An ecological overview of cloning in Metazoa. In: Jackson, J. B. C., Buss, L. W., Cook, R. E. (eds.) Population biology and evolution of clonal organisms. Yale University Press, New Haven, p. $153-186$

Hughes, T. P., Connell, J. H. (1987). Population dynamics based on size or age? A reef-coral analysis. Am. Nat. 129: 818-829

Hughes, T. P., Jackson, J. B. C. (1980). Do corals lie about their age? Some demographic consequences of partial predation, fission and fusion. Science 209: 713-715

Jackson, J. B. C., Buss, L. W., Cook, R. E. (1985). Population biology and evolution of clonal organisms. Yale University Press, New Haven

Jackson, J. B. C., Winston, J. E. (1981). Modular growth and longevity in bryozoans. In: Larwood, G. P., Nielsen, C. (eds.) Recent and fossil Bryzoa. Olsen and Olsen, Fredensborg, p. 121-126

Jokiel, P. L. (1985). Lunar periodicity of planula release in the reef coral Pocillopora damicornis in relation to various environmental factors. Proc. 5th int. coral Reef Congr. 4 307-312

Kinzie, R. A. (1970). The ecology of the gorgonians (Cnidaria, Octocorallia) of Discovery Bay, Jamaica. Ph.D. thesis, Yale University, New Haven

Kinzie, R. A. (1974). Plexaura homomalla: the biology and ecology of a harvestable marine resource. In: Bayer, F. M., Weinheimer, A. J. (eds) Prostaglandins from Plesuara homomalla. Univ. Miami Press, Coral Gables, p. 22-38

Kojis, B. L. (1986a). Sexual reproduction in Acropora (Isopora) (Coelenterata: Scleractinia). I. A. cuneata and A. palifera on Heron Island Reef, Great Barrier Reef. Mar. Biol. 91: 291-309

Kojis, B. L. (1986b). Sexual reproduction in Acropora (Isopora) (Coelenterata: Scleractinia). II. Latitudinal variation in A. palifera from the Great Barrier Reef and Papua New Guinea. Mar. Biol. 91: 311-318

Kojis, B. L., Quinn, N. J. (1981). Aspects of sexual reproduction and larval development in the shallow water hermatypic coral, Goniastrea australensis (Edwards and Haime, 1857). Bull. mar. Sci. 31: 558-573

Lasker, H. R. (1983). Vegetative reproduction in the octocoral Briareum asbestinum (Pallas). J. exp. mar. Biol. Ecol. 72: $157-169$

Margalef, R. (1984). Ecología. Editorial. Omega, Barcelona

Martin, E. (1982). Ciclo reproductivo, proporción sexual y fecundidad del coral blando Plexaura homomalla (Esper.) en el Mar Caribe Mexicano. (Octocoralla: Plexauridae). An. Inst. Cienc. Mar Limnol. Univ. Nal. Autón. Mexico 9: $359-380$

McKinney, F. K., Jackson, J. B, C. (1991). Bryozoan evolution. University of Chicago Press, Chicago

Medawar, P. B. (1957). The uniqueness of the individual. Methuen, London

Mitchell, N. D., Dardeu, M. R., Schroeder, W. W. (1993). Colony morphology, age structure, and relative growth of two gorgonian corals, Leptogorgia hebes (Verrill) and Leptogorgia virgulata (Lamarck), from the northern Gulf of Mexico. Coral Reefs 12: 65-70

Murdock, G. R. (1978). Circulation and digestion of food in the gastrovascular system of gorgonian octocoral (Cnidaria; anthozoa). Bull. mar. Sci. 28: 363-370

Oliver, J. F. (1984). Intra-colony variation in the growth of Acropora formosa: extension rates and skeletal structure of white (zooxanthellae-free) and brown-tipped branches. Coral Reefs 3: 139-147

Palumbi, S. R., Jackson, J. B. C. (1983). Ageing in modular organisms: ecology of zooid senescence in Steginoporella sp. (Bryozoa: Cheilostomata). Biol. Bull. 164: 267-78

Richmond, R. H. (1987). Energetic relationships and biogeographical differences among fecundity, growth and reproduction in the reef coral Pocillopora damicornis. Bull. mar. Sci. 41: 594-604

Rinkevich, B., Loya, Y. (1979). The reproduction of the red sea coral Stylophora pistillata. II. Synchronization in breeding and seasonality of planulae shedding. Mar. Ecol. Prog. Ser. 1: 145-152

Rinkevich, B., Loya, Y. (1987). Variability in the pattern of sexual reproduction of the coral Stylophora pistillata at Eilat, Red Sea: a long-term study. Biol. Bull. 173: 335-344

Silander, J. A. Jr (1985). Microevolution in clonal plants. In: Jackson, J. B. C., Buss, L. W., Cook, R. E. (eds.) Population biology and evolution of clonal organisms. Yale University Press, New Haven, p. 107-152

Soong, K., Lang, J. C. (1992). Reproductive integration in reef corals. Biol. Bull. 183: 418-431

Strehler, B. L. (1961). Ageing in coelenterates. In: Lenhoff, H. M., Loomis, W. F. (eds.) The biology of Hydra and some other coelenterates. University of Miami Press, Coral Gables, p. 373-398

Szmant-Froelich, A. M. (1985). The effect of colony size on the reproductive ability of the Caribbean coral Montastrea annularis (Ellis and Solander). Proc. 5th int. coral Reef Congr. 4: 295-300

Szmant-Froelich, A. M. (1986). Reproductive ecology of Caribbean reef corals. Coral Reefs 5: 43-53

Theodor, J. (1967). Contribution a l'étude des gorgones. VII. Ecologie et comportement de la planula. Vie Milieu 18: 291-301

Todd, C. D. (1985). Reproductive strategies of north temperate rocky shore invertebrates. In: Moore, P. G., Seed, R. (eds.) The ecology of rocky coasts. Hodder and Stoughton Educational, London, p. 203-219

Tranter, P. R. G., Nicholson, D. N., Kinchington, D. (1982). A description of the spawning and post-gastrula development of the cool temperate coral Caryophyllia smithii (Stokes and Broderip). J. mar. biol. Ass. U.K. 62: $845-854$

Vighi, M. (1970). Ricerche sul ciclo reproductivo del corallo rosso (Corallium rubrum (L)) del Promontorio di Porfino. Atti. Accad. Lincei. Roma (Ser. 8) 10: 1-26

Wahle, C. M. (1983). The roles of sex, size and injury in sexual reproduction among Jamaican gorgonians. Am. Zool. 24: 961

Wallace, C. C. (1985). Reproduction, recruitment and fragmentation in nine sympatric species of the coral genus Acropora. Mar. Biol. 88: 217-233

Williams, G. C. (1957). Pleiotropy, natural selection, and the evolution of senescence. Evolution 11: 398-411

Zar, J. H. (1984). Biostatistical analysis. Prentice-Hall, Englewood Cliffs, NJ 